\title{
Garra kalpangi, a new cyprinid fish species (Pisces: Teleostei) from upper Brahmaputra basin in Arunachal Pradesh, India
}

\author{
K. Nebeshwar ${ }^{1}$, Kenjum Bagra ${ }^{2}$ \& D.N. Das ${ }^{3}$ \\ 1,2 Centre of Biodiversity, Department of Zoology, Rajiv Gandhi University, Rono Hills, Itanagar, Arunachal Pradesh 791112, India \\ ${ }^{3}$ Department of Zoology, Rajiv Gandhi University, Rono Hills, Itanagar, Arunachal Pradesh 791112, India \\ Present address: ${ }^{1}$ Department of Life Science (Fish Section), Manipur University, Canchipur, Imphal, Manipur 795003, India \\ ${ }^{2}$ Arunchal Pradesh Biodiversity Board, Itanagar, Arunachal Pradesh 791113, India \\ Email: ${ }^{1}$ knebeshwar@yahoo.com, ${ }^{2}$ bagrakb@gmail.com, ${ }^{3}$ dndas321@rediffmail.com (corresponding author)
}

Date of publication (online): 26 February 2012 Date of publication (print): 26 February 2012 ISSN 0974-7907 (online) | 0974-7893 (print)

Editor: K. Rema Devi

\section{Manuscript details:}

Ms \# 01703

Received 06 January 2007

Final received 04 May 2011

Finally accepted 08 January 2012

Citation: Nebeshwar, K., K. Bagra \& D.N. Das (2011). Garra kalpangi, a new cyprinid fish species (Pisces: Teleostei) from upper Brahmaputra basin in Arunachal Pradesh, India. Journal of Threatened Taxa 4(2): 2353-2362.

Copyright: (c) K. Nebeshwar, Kenjum Bagra \& D.N. Das 2012. Creative Commons Attribution 3.0Unported License. JoTT allows unrestricted use of this article in any medium for non-profit purposes, reproduction and distribution by providing adequate credit to the authors and the source of publication.

Author Details: K. Nebeshwar is well versed with fish taxonomy and is actively engaged in exploration of ichthyofauna and description of new taxa in Manipur and Arunachal Pradesh. Kenjum Bagra is actively engaged in ichthyofaunal exploration and documentation in Arunachal Pradesh. D.N. DAS is engaged in teaching fisheries as well as research and development activities on the subject in the region.

Author Contribution: See end of this article

Acknowledgement: The authors are gratefu o the University Grants Commission, New Delhi for financial assistance. The authors are also very thankful to Dr. B.A. Laskar, Research Assistant, RGU-DCFR collaborative project Rajiv Gandhi University, Arunachal Pradesh and Mr. Lakpa Tamang of G.B. Pant Institute of Himalayan Environment and Development, Itanagar Arunachal Pradesh for their contribution in finalising the manuscript.
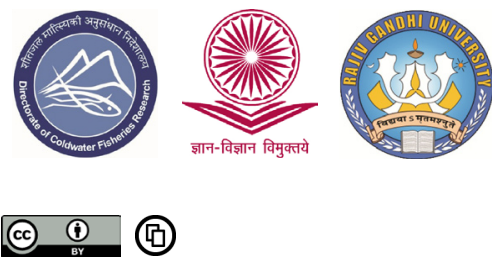

OPEN ACCESS | FREE DOWNLOAD
Abstract: A new cyprinid species, Garra kalpangi is described from the Kalpangi River (Brahmaputra basin) in Arunachal Pradesh, India. The species is closely similar to $G$. gravelyi, G. rotundinasus and $G$. elongata in having a shared character i.e. a weakly developed proboscis. It is distinguishable from G. gravelyi for the absence of indistinct black spot at the bases of branched dorsal fin rays and lateral stripes on the side of the body. However, G. rotundinasus possesses lateral stripe along the lateral line. Further, the absence of transverse groove at the tip of snout and longitudinal black band in medial coudal fin differentiated it from G. elongata. The detail comparative account of the 16 available species of northeastern India confirmed its distinct diagnosis as a new species under the genus. Accordingly, after thorough investigation, the taxonomic keys for all the available species under the genus from the region have also been erected in this article.

Keywords: Freshwater fish, Himalayan foot hill, Kalpangi River, new description.

\section{INTRODUCTION}

The cyprinid fish genus Garra Hamilton, 1822, is a bottom dwelling fish. The genus consists of approximately 70 species in the region from Borneo, southern China and southern Asia through Middle East Asia, Arabian Peninsula and East Africa to West Africa (Zhang \& Chen 2002). In the first revision of the genus, adopting Garra Hamilton as the generic name, Hora (1921) described seven new species from the Himalayan foothill drainages, viz. G. annandalei from Assam and streams at the base of the Darjeeling Himalaya, G. abhoyai from neighborhood hill streams of Ukhrul District in Manipur, G. naganensis from Senapati stream in Naga Hills, Assam (now in Manipur), G. prashadi from Malwa Tal, Uttar Pradesh (now in Uttarakhand), G. chaudhurii from Darjeeling District in northern Bengal, G. jenkinsonianum from Sita Nullah, Paresnath Hills in Bengal and G. kempi from Abor Hills, Assam (now in Arunachal Pradesh). Menon (1964) recognized 38 species and kept the species status of G. abhoyai, G. chaudurii, G. prashadi and G. jenkinsonianum as junior synonyms of G. rupecula, G. annandalei, G. lamta and G. mullya, respectively. Other known species in the Himalayan foothills and the adjoining regions draining into the Brahmaputra and Ganga basins include G. rupecula, G. lissorhynchus, G. lamta, G. gotyla, and G. nasuta (Hora 


\section{1; Menon 1964).}

In subsequent publications (Vishwanath \& Sarojnalini 1988; Vishwanath 1993; Kosygin \& Vishwanath 1998; Vishwanath \& Kosygin 2000; Zhang \& Chen 2002; Kullander \& Fang 2004; Vishwanath \& Shanta 2005; Zhang 2006; Vishwanath \& Linthoingambi 2008; Nebeshwar et al. 2009) have also described or revalidated or reviewed several species from the Brahmaputra and Chindwin basins in northeastern region, Irrawaddy basin in Myanmar and China. Vishwanath \& Linthoingambi (2008) revalidated the species, $G$. abhoyai from being a junior synonym of $G$. rupecula.

There are seven species of Garra, namely, $G$. lissorhynchus, G. annandalei, G. gotyla, G. kempi, G. lamta, G. mcclellandi and G. naganensis reported from Arunachal Pradesh (Nath \& Dey 2000). Comparison of a species population of the genus Garra having a weakly developed proboscis, collected from the Kalpangi River in Arunachal Pradesh with the species distributed in the Himalayan foothill drainages of northeastern India and the species from the upper Irrawaddy basin in China and the Rakhine states in Myanmar reveals that the species represents an undescribed species, herein described as Garra kalpangi sp. nov. (Fig. 1).

\section{MATERIAL AND METHODS}

The descriptions are based on formalin preserved specimens. Counts, measurements and terminology follow Kullander \& Fang (2004) and measurements were taken from point to point with digital calipers to $0.1 \mathrm{~mm}$. Fin rays and numbers of scales were counted under a zoom stereoscopic microscope. Lateral line scales counted from the anterior most scale in contact with the shoulder girdle to the last scale on the caudal fin; lateral transverse scales above lateral line counted from dorsal-fin origin to lateral line obliquely ventrad and caudad and scales below lateral line counted from anal-fin origin to lateral line obliquely dorsad and rostrad. Additional terminology used for description of disc follows Zhang et al. (2002). Other additional measurement techniques are as follows: disc width is the widest portion of the lower lip, and disc length is taken from anterior mid-point of the anterior papillate skin fold to the posterior mid-point of the posterior margin of the mental disc. Lateral line scales were counted from the anterior most scale in contact with the shoulder girdle to the last scale on the caudal fin. Measurements of different morphometric parameters are given in percentages of standard length. For vertebral count, two specimens were dissected and

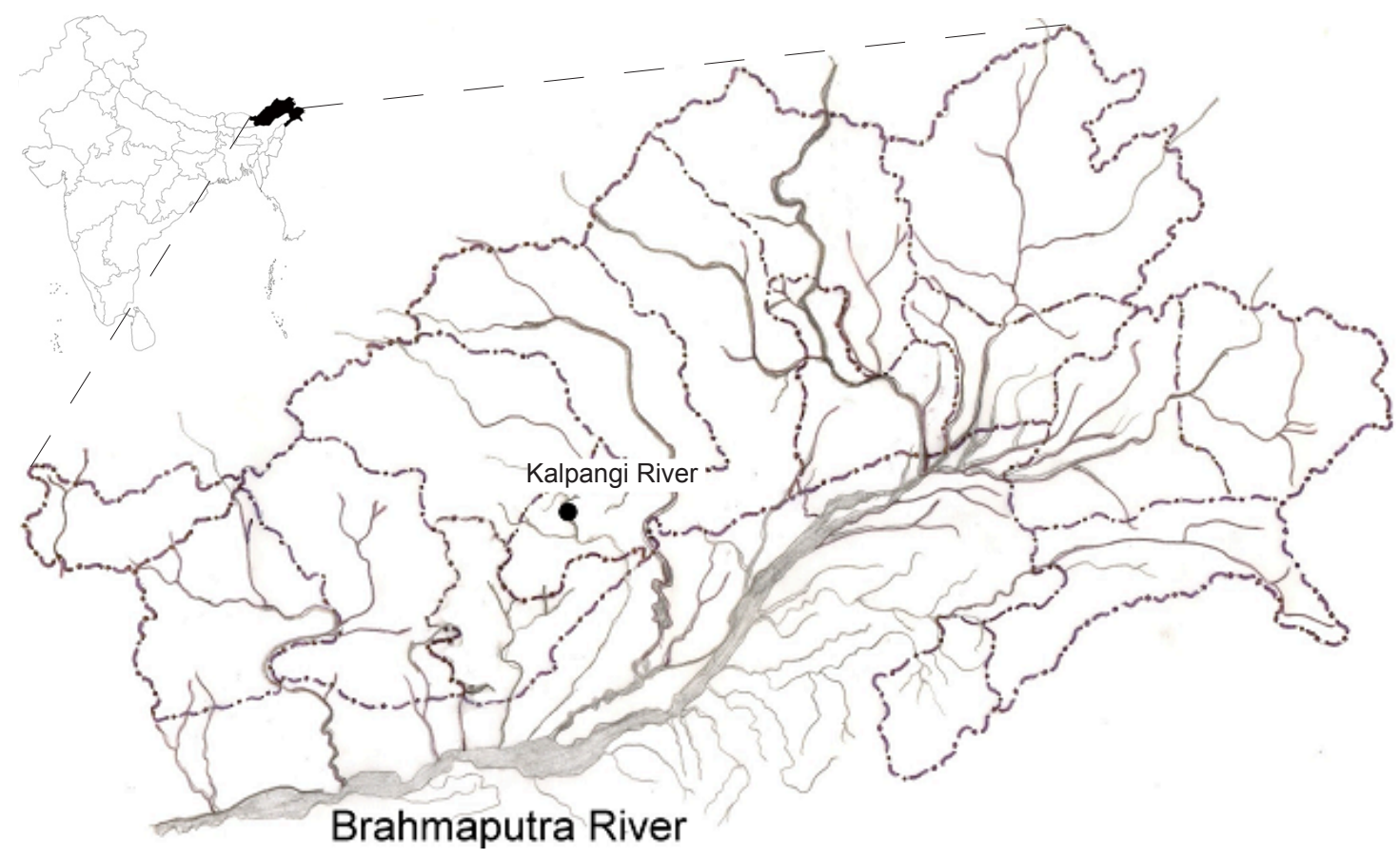

Figure 1. Collection site (marked as black spot) of Garra kalpangi sp. nov. in Kalpangi River, Lower Subansiri District, Arunachal Pradesh, India 
stained with alizarin S. Abdominal vertebrae were counted from the first four vertebrae of the weberian apparatus to the last vertebra bearing pleural rib and caudal vertebrae were counted from the vertebra immediately posterior to anal fin pterygiophore. Some snout structures are addressed here with uniform terminology. The sublachrymal groove originates from the base of the rostral barbel and usually extends horizontally above the level of the groove of the rostral cap.

Comparison of the present material with $G$. rotundinasus, $G$. gravelyi, $G$. rupecula, $G$. lamta and other known species distributed in China and Myanmar are made on published description, while for comparison with other congeners, their holotype and paratype are personally examined and measured. Specimens are deposited in the Rajiv Gandhi University Museum of Fishes (RGUMF).

\section{Garra kalpangi sp. nov. (Image 1)}

\section{Material examined}

Holotype: 18.vii.2005, 60.0mm SL, location $27^{0} 25^{\prime} 54^{\prime \prime N} \& 93^{\circ} 46^{\prime} 42$ 'E, altitude 843m, Kalpangi River at Yachuli (Brahmaputra River system), Lower Subansiri District, Arunachal Pradesh, India, coll. Kenjum Bagra, RGUMF-0006.

Paratype: 9 exs., same data as holotype, RGUMF-0007, 50.0-72.4 mm SL,

\section{Diagnosis}

Garra kalpangi sp. nov. is characterized from its congeners of the Himalayan foothills by the combination of characters: two pairs of barbels, a poorly developed proboscis represented by a squarish area in front of the nostrils and 16 circumpeduncular scales. It is closely similar to G. gravelyi, G. rotundinasus and $G$. elongata in having a weakly developed proboscis on the snout. Garra kalpangi sp. nov. can be differentiated from $G$. gravelyi in having branched dorsal-fin rays 8 (vs. 7), branched pectoral-fin rays 1012 (vs. 13), predorsal scales 10-11 (vs. 8-9), absence (vs. presence) of indistinct black spots at the bases of the branched dorsal-fin rays, absence (vs. presence) of lateral stripes on side of body. Garra kalpangi sp. nov. can be differentiated from $G$. rotundinasus in having branched pectoral-fin rays 10-12 (vs.13-15), lateral line scales 32-33 (vs. 36-37), scales between vent and anal-fin origin 3 (vs. 5), transverse scale rows above lateral line $3 \frac{1}{2}$ (vs. $2 \frac{1}{2}$ ), transverse scale rows below lateral line $3 \frac{1}{2}-4$ (vs. $2^{1 / 2}-3$ ), circumpeduncular scales 16 (vs. 12), absence (vs. subtle presence) of lateral stripe along lateral line. Garra kalpangi sp. nov. can be differentiated from $G$. elongata in having lateral line scales 32-33 (vs. 40-41), predorsal scales 10-11 (vs. 14-15), branched dorsal-fin rays 8 (vs.7), absence (vs. presence) of transverse groove at tip of snout, absence (vs. presence) of pleated papilliferous fold at corner of mouth, absence (vs. presence) of a wide submarginal band on dorsal fin, absence (vs. presence) of a longitudinal median black band on caudal fin.

\section{Description}

Measurements and counts taken from 10 specimens, 50.0-72.4 mm SL are given in Table 1. General body

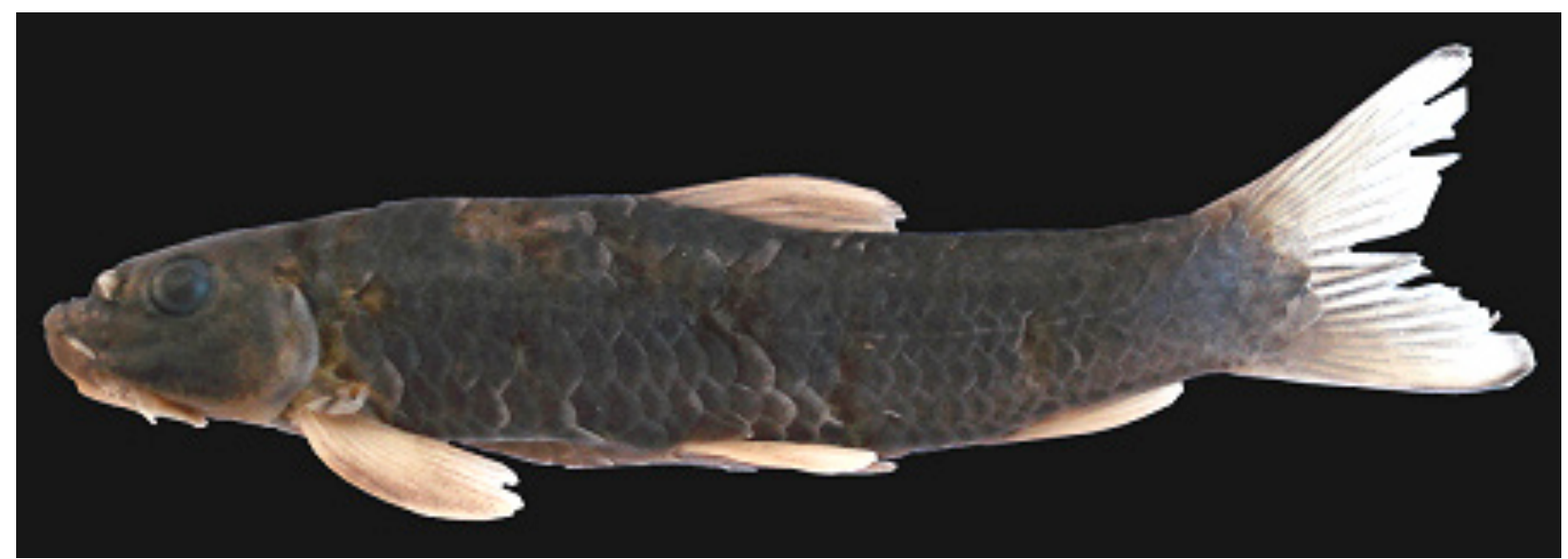

Image 1. Garra kalpangi sp. nov., holotype, RGUMF-0006, 60mm SL.; Lateral view 


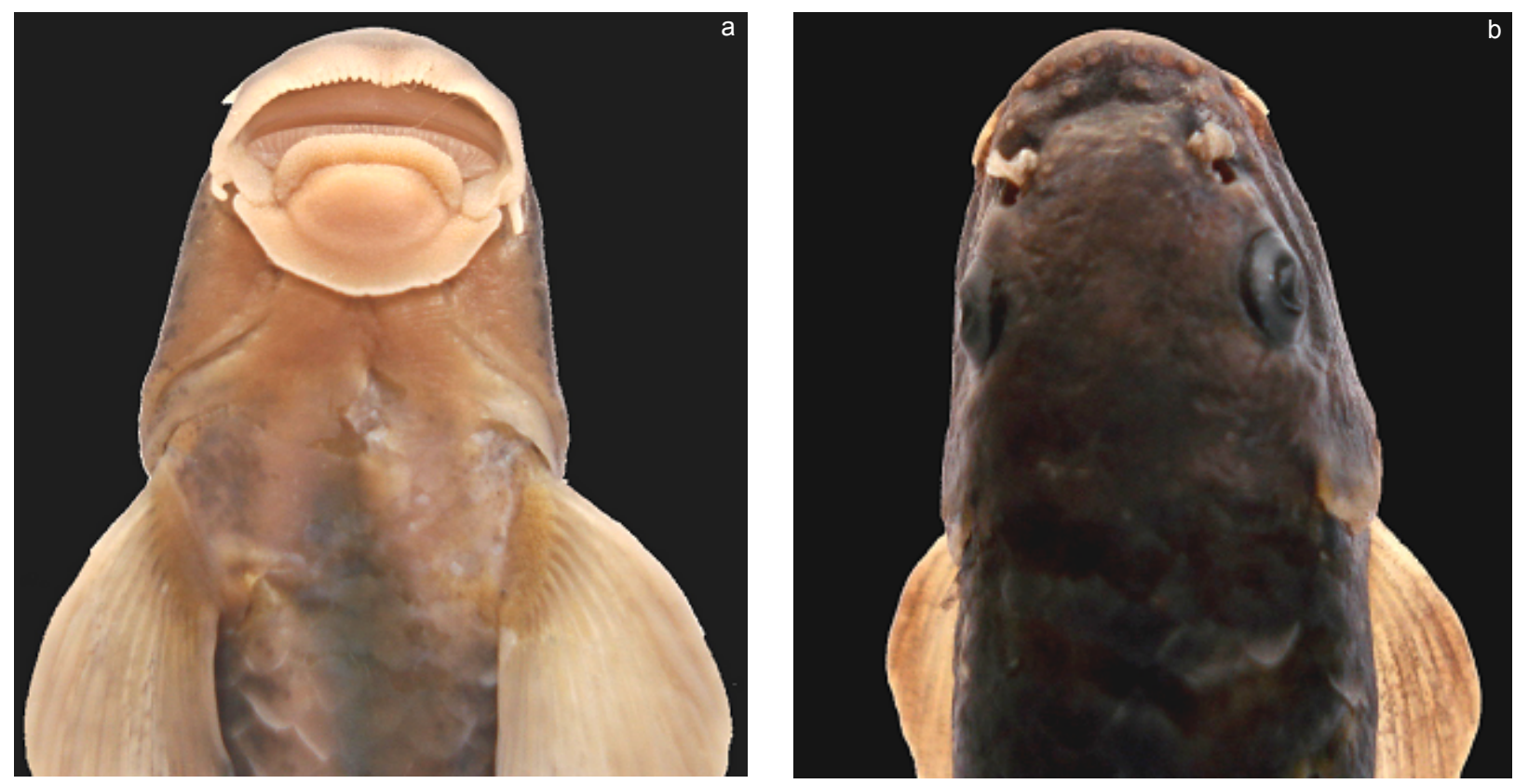

Image 2. Garra kalpangi sp. nov., holotype. a - ventral view of disc; b - dorsal view of head.

appearance in Image 1 and morphology of the mental adhesive disc and head dorsum are shown in Images $2 \mathrm{a}-\mathrm{b}$ respectively.

Body elongate, compressed laterally, more on caudal peduncle region; dorsal profile smoothly arched to dorsal-fin origin, then straight from posterior end of dorsal-fin base to caudal-fin base; ventral profile flat from head to chest, then more or less round up to pelvic-fin origin, and straight from pelvic to caudal-fin base. Head small, more or less depressed with a convex interorbital space; height less than length; width greater than height. Snout blunt, without transverse groove on tip, with a few minute to large tubercles across its tip and lateral sides anterior to nostrils; sublachrymal groove free from lateral groove of rostral cap; a poorly developed proboscis represented by a squarish area in the front of the nostrils; rostral lobe absent. Eyes placed dorsolaterally in middle of head.

Two pairs of barbels; rostral ones anteroventrally located, shorter than eye diameter; maxillary ones at corner of mouth, shorter than rostral ones. Rostral cap well developed, moderately crenulated, and with a wide papillate margin; separated from the upper jaw by a deep groove and laterally continuous with lower lip by a flat papillate connective tissue. No upper lip in the form of papillose tissue and no papillose fold in the corner of mouth. Upper jaw entirely covered by rostral cap. Lower lip modified into a mental adhesive disc. Disc elliptical, shorter than wide; anterior margin modified to form a transverse, flat, fleshy and crescentic skin fold covered by numerous tiny papillae; anteriorly separated from lower jaw by a deep groove running along lower jaw and posteriorly bordered in a deep groove with central callous pad; lateral and posterior margin surrounding central callous pad papillate and free; posteriormost margin not reaching vertical from posterior margin of eye.

Dorsal fin with 2(4), 3(5) simple and 8(9) branched rays; last simple ray shorter than or equal to HL; distal margin slightly concave; originated closer to snout tip than to caudal-fin base, inserted anterior to pelvic fin; first and second branched rays longest, last branched ray not extending to vertical from anal-fin origin. Pectoral fin with one simple and 10(3), 11(3), 12(3) branched rays, reaching beyond midway to pelvic-fin origin; its length less than or equal to HL; subacuminate margin; fourth branched ray longest. Pelvic fin with one simple and 7(3), 8(6) branched rays, reaching beyond midway to anal-fin origin, surpassing the vent; its outer margin blunt; second branched ray longest. Anal fin short with 2(6), 3(3) simple and 5(9) branched rays; first branched ray longest, straight posterior margin; tip extending to base of caudal fin or slightly shorter; origin of anal fin closer to caudalfin base than to pelvic-fin origin. Caudal fin deeply emarginate; lobe tips pointed, $10^{\text {th }}$ ray shortest; lobes 
Table 1. Morphometric characters of G. kalpangi sp. nov.

\begin{tabular}{|c|c|c|c|}
\hline \multirow[t]{2}{*}{ Morphometrics } & \multirow[t]{2}{*}{ Holotype } & \multicolumn{2}{|c|}{$\begin{array}{c}10 \text { specimens including } \\
\text { holotype }\end{array}$} \\
\hline & & Min-Max & Mean $\pm S D$ \\
\hline Standard length & 60.4 & $50.0-72.4$ & \\
\hline \multicolumn{4}{|l|}{ In \% SL } \\
\hline body depth & 21.8 & $18.9-23.8$ & $21.4 \pm 1.63$ \\
\hline head length & 24.3 & $21.1-24.7$ & $22.9 \pm 1.24$ \\
\hline head height at nape & 14.8 & $14.6-16.7$ & $15.8 \pm 0.83$ \\
\hline head width at opercle & 18.9 & $17.3-19.3$ & $18.6 \pm 0.78$ \\
\hline snout length & 12.0 & $9.1-11.6$ & $10.4 \pm 1.05$ \\
\hline eye diameter & 5.8 & $5.1-6.7$ & $5.8 \pm 0.54$ \\
\hline inter-orbital space & 10.0 & $8.7-10.1$ & $9.5 \pm 0.55$ \\
\hline body width at anal fin & 10.2 & $8.6-10.3$ & $9.9 \pm 1.13$ \\
\hline body width at dorsal fin & 16.5 & $16.3-18.1$ & $17.1 \pm 0.61$ \\
\hline caudal peduncle length & 16.5 & $16.0-17.5$ & $16.9 \pm 0.59$ \\
\hline caudal peduncle height & 13.6 & $12.8-15.2$ & $13.6 \pm 0.93$ \\
\hline dorsal-fin length & 22.6 & $21.9-25.7$ & $23.1 \pm 0.75$ \\
\hline dorsal-fin base length & 14.6 & $14.5-16.2$ & $15.4 \pm 0.73$ \\
\hline pectoral-fin length & 20.7 & $20.4-24.5$ & $21.5 \pm 1.35$ \\
\hline ventral-fin length & 18.0 & $17.8-21.3$ & $18.8 \pm 1.19$ \\
\hline anal-fin length & 18.2 & $17.9-20.0$ & $19.0 \pm 0.82$ \\
\hline anal-fin base length & 6.8 & $6.7-7.7$ & $7.4 \pm 0.47$ \\
\hline upper caudal-fin lobe length & 26.4 & $26.0-30.0$ & $27.7 \pm 1.34$ \\
\hline lower caudal-fin lobe length & 27.3 & $26.3-31.4$ & $28.6 \pm 1.64$ \\
\hline median caudal-fin rays length & 18.2 & $17.8-20.9$ & $19.2 \pm 1.10$ \\
\hline pre-anal length & 78.8 & $74.4-80.4$ & $76.9 \pm 2.21$ \\
\hline pre-anus length & 70.2 & $69.5-74.9$ & $72.9 \pm 3.58$ \\
\hline pre-ventral length & 52.7 & $51.1-56.1$ & $54.1 \pm 1.71$ \\
\hline pre-dorsal length & 49.3 & $43.9-50.2$ & $47.5 \pm 2.54$ \\
\hline ventral-anal distance & 22.1 & $21.3-24.5$ & $23.5 \pm 1.22$ \\
\hline vent-anal distance & 5.6 & $4.4-6.2$ & $5.3 \pm 0.73$ \\
\hline disc length & 9.2 & $8.3-9.9$ & $9.2 \pm 0.52$ \\
\hline disc width & 11.8 & $10.5-12.1$ & $11.3 \pm 0.70$ \\
\hline callous pad length & 5.3 & $4.8-5.5$ & $5.1 \pm 0.26$ \\
\hline callous pad width & 7.5 & $7.3-8.1$ & $7.7 \pm 0.29$ \\
\hline \multicolumn{4}{|l|}{ In \% HL } \\
\hline snout length & 44.6 & $41.3-49.3$ & $44.6 \pm 2.05$ \\
\hline eye diameter & 23.2 & $23.1-27.8$ & $25.4 \pm 1.45$ \\
\hline inter-orbital space & 37.3 & $38.7-43.4$ & $41.2 \pm 1.81$ \\
\hline disc length & 25.2 & $34.6-38.1$ & $36.5 \pm 1.44$ \\
\hline disc width & 48.1 & $46.0-54.4$ & $49.4 \pm 3.45$ \\
\hline callous pad length & 19.9 & $19.5-24.4$ & $22.0 \pm 1.71$ \\
\hline callous pad width & 26.9 & $32.9-35.0$ & $33.5 \pm 1.19$ \\
\hline
\end{tabular}

equally long or lower slightly longer.

Lateral line complete with 32(2), 33(7) scales. Scales in transverse row above lateral line $3 \frac{1}{1} 2(9)$ and below lateral line 31/2(8), 4(1). Circumpeduncular scales 16(9). Predorsal scales 10(6), 11(3); scales arranged regularly. Long axillary scale at base of pelvic fin reaching beyond its base. A row of 3 scales between vent and anal-fin base.

Total vertebrae 31(2); abdominal vertebrae 16(2); caudal vertebrae 12(2). Gill rakers thin and weakly developed 11(1), 12(1). Air chamber bipartite; anterior chamber oval; posterior one small and conical, about $2 / 3$ length of anterior chamber.

\section{Colour in preservative}

Dorsum and sides of head dark gray; head, chest, and abdomen yellowish. Dorsal, anal, pelvic, and pectoral fins grayish-white. Caudal fin light grayish with a thin, short marginal stripe each on tip of upper lobe dorsally and on tip of lower lobe ventrally; in three specimens, with more or less indistinct grayish wide band along middle rays. A black spot at the upper angle of gill opening.

\section{Etymology}

Name is given as noun in apposition after the name of the River Kalpangi in Yazali, Lower Subansiri District, Arunachal Pradesh from where the specimen was first collected.

\section{DISCUSSION AND CONCLUSIONS}

There are altogether 15 valid species of Garra known from the Himalayan foothills and distributed in the Ganga, Brahmaputra and Chindwin basins in northeastern India. The species are G. kempi Hora, G. annandalei Hora, G. naganensis Hora, G. rupecula (McClelland), G. abhoyai Hora, G. lamta Hamilton, G. arupi Nebeshwar, Vishwanath \& Das, G. lissorhynchus (McClelland), G. manipurensis Vishwanath \& Sarojnalini, G. paralissorhynchus Vishwanath \& Santa, G. compressus Kosygin, \& Vishwanath, G. elongata Vishwanath \& Kosygin, G. gotyla Gray, G. nasuta (McClelland), and G. litanensis Vishwanath. Within these 15 species of the genus, former 11 species depict distinction of either absence of proboscis or weakly developed proboscis compared 
to Garra kalpangi sp. nov. whereas, later 4 species show the presence of strong proboscis.

When Garra kalpangi sp. nov. is further compared with the most similar species: the Salween form, $G$. gravelyi, the Irrawaddy form, G. rotundinasus, and the Chindwin form, G. elongata, it also differs from $G$. gravelyi in having a wider head (1.18-1.28 in HL vs.1.39-1.48); from $G$. rotundinasus in having a deeper head (14.6-16.7 \% SL vs. 12.5-14.4), and caudal peduncle (12.8-15.2 \% SL vs. 10.8-11.8); larger eye (23.1-27.8 \% HL vs. 13.8-18.6); narrower disc (46.0-54.4\% HL vs. 68.8-82.3), and interorbital space (38.1-43.4\% HL vs. 44.8-56.9); and shorter disc (34.6-38.1 \% HL vs. 46.8-60.8); from $G$. elongata in having longer dorsal-fin base (14.5-16.2 $\%$ SL vs. 11.2-12.6), pectoral fin (20.4-24.5\%SL vs. 18.2-19.9), pre-pelvic distance (51.1-56.1\% SL vs. 46.9-49.7), and pre-anal distance (69.5-74.9\% SL vs. 60.2-64.3); shorter central callous pad (4.8-5.5\% SL vs. 7.2-8.1), and caudal peduncle (16.0-17.5\% SL vs. 19.2-20.7).

Comparison in morphometric data and meristic count of Garra kalpangi sp. nov. with other known valid species of Himalayan foothill regions and its ranges is shown in the Table 2 and Appendix 1. G. kalpangi sp. nov. further differs from $G$. annandalei in having absence (vs. presence) of upper lip and a pleated papilliferous fold in the corner of mouth; rostral cap groove shallow, short, not extending up to base of rostral barbel (vs. deep, long, extending up to base of rostral barbel); from G. abhoyai in having absence (vs. presence) of w-shaped band on caudal fin; from G. arupi in the absence (vs. presence) of a submarginal black band of dorsal fin and thin stripes on caudal peduncle.

Garra lissorhynchus, G. paralissorhynchus and G. manipurensis have a rostral lobe on tip of the snout, which can easily differentiate the three species from $G$. kalpangi sp. nov. Rostral lobe is a triangular section of the snout anterodorsal to the base of the anterior barbel; well demarcated but not elevated from the rest of the snout (Kullander \& Fang 2004). G. kalpangi sp. nov. further differs from $G$. lissorhynchus and $G$. paralissorhynchus in the absence (vs. presence) of w-shaped band on caudal fin.

Garra kalpangi sp. nov. further differs from $G$. rupecula in having less lateral line scales (32-33 vs. 35 ); absence (vs. presence) of two rows of open pores, each on interorbital and internarial region; from $G$. lamta in having absence (vs. presence) of broad lateral band from gill-opening to base of caudal fin with incomplete dark narrow stripes above and below it, especially in the posterior half of body; absence (vs. presence) of a black spot at the base of the caudal fin and a deep transverse groove at the tip of the snout.

Garra gotyla, G. nasuta and $G$. litanensis are characteristic in having a prominent proboscis with large tubercles, a distinct transverse lobe at the tip of the snout with large tubercles, black spots at the bases of branched dorsal-fin rays (Menon 1964; Vishwanath 1993). Only these characters can easily differentiate the three species from $G$. kalpangi sp. nov.

When Nath \& Day (2000) reported seven species of Garra in Arunachal Pradesh, a peninsular form, G. mcclellandi was also included. His identification of $G$. mcclellandi in the Himalayan foothill region is ambiguous. However, G. kalpangi sp. nov. differs from G. mcclellandi in the absence (vs. presence) of a distinct dark midlateral stripe from the gill opening to the base of the caudal fin; snout moderately rounded (vs. conical); absence (vs. presence) of a transverse groove at the tip of the snout; less lateral line scales (31-32 vs. $35-38)$; more predorsal scales (10-12 vs. 8-10).

Kullander \& Fang (2004) described seven new species found in different streams of the Rakhine state in Myanmar. The species are Garra propulvinus, $G$. vittatula, G. rakhinica, G. flavatra, G. nigricollis, $G$. spilota and $G$. poecilura. Most species except ( $G$. spilota) have a distinct rostral lobe on snout. Only this character can easily differentiate the above six species from G. kalpangi sp. nov. G. kalpangi sp. nov. differs from G. spilota in the absence (vs. presence) of blotches on the body; absence (vs. presence) of pleated papilliferous fold at the corner of mouth between exposed lower jaw and lower lip; less transverse scale rows above lateral line ( $3 \frac{1}{2}$ vs. $4^{1 / 2}$ ), scale rows below lateral line (31/2 vs. $\left.4 \frac{1}{2}\right)$.

The other known congeners above Garra gravelyi and $G$. rotundinasus distributed in China are $G$. orientalis Nichols, G. qiaojiensis $\mathrm{Wu} \&$ Yao, $G$. tengchongensis Zhang \& Chen in the upper Irrawaddy basin and $G$. nujiangensis Chen, Zhao \& Yang in Salween basin (Zhang \& Chen 2002; Zhang 2006; Chen et al. 2009). All the species (except G. tengchongensis and $G$. nujiangensis) have prominent proboscis on the 
snout, which is also a differentiating character from the present new species. G. kalpangi sp. nov. differs from the latter two species in having less lateral line scales (32-33 vs. 37-38 in G. tengchongensis; 48-50 in G. nujiangensis); more circumpeduncular scales (16 vs. 12 in G. tengchongensis; 12-14 in G. nujiangensis).

There is a nominal species distributed in northeastern India, viz., Garra chaudhurii Hora considered as a juniour synonym of $G$. annandalei (Menon 1964). In the original description of $G$. chaudhurii, the characters i.e. variation in the shape of disc among specimens, presence of 32-33 lateral line scales are mentioned. However, variation of disc is not observed among different sizes of 25 specimens of $G$. annandalei deposited in the RGUMF. The differentiating characters and geographical distribution of $G$. gotyla and $G$. nasuta are also very ambiguous. So, a review of the species based on the materials collected from their respective type localities is highly needed. In most Garra species, the lateral deep groove of the rostral cap is continuous to the shallow sublachrymal groove extending from the base of the rostral barbel (Fig. 2a-d). In G. kalpangi sp. nov. and G. paralissorhynchus, the grooves are not connected free from each other. In the former species, the sublachrymal groove runs horizontally above the level of the groove of the rostral cap and in the latter, the sublachrymal groove runs horizontally below the level of the groove of rostral cap. In G. annandalei,
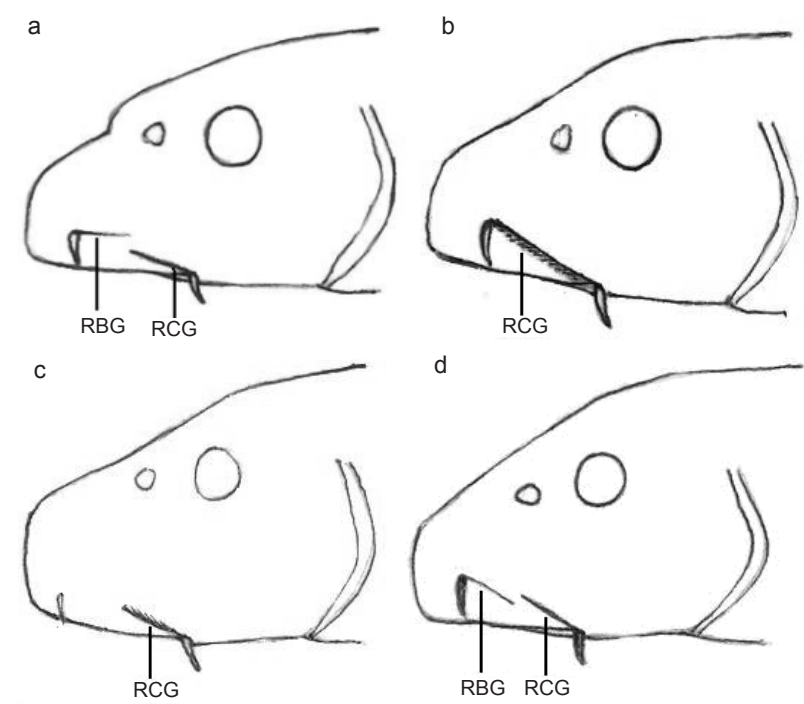

Figure 2. a - Garra kalpangi sp. nov.; b - Garra annandalei; c - Garra abhoyai; d - Garra paralissorhynchus. RCG - Rostral cap groove; RBG - Rostral barbel groove the rostral cap groove is deep and runs upto the base of rostral barbel. So, no two different grooves can be seen. The groove of the rostral cap extends to the base of the rostral barbel. In G. naganensis, $G$. lissorhynchus and $G$. elongata, the rostral cap groove continues to the shallow sublachrymal groove. In $G$. abhoyai the sublachrymal is absent or present as an indistinct line and continuous to the groove of rostral cap.

\section{Comparative material}

Garra elongata: MUMF 2311, holotype, 86.2 mm SL; MUMF 2308-2310, paratype, 3 exs., 72.0$80.8 \mathrm{~mm}$ SL, a small stream near Tolloi, Ukhrul district, Manipur (Chindwin basin), coll. L. Kosygin, 12.xi.1997. - uncatalogued specimens, 4 exs. 63.2$112.5 \mathrm{~mm}$ SL, Challou River at Challou, Ukhrul district, Manipur (Chindwin basin), coll. Kingson, May 2005. Garra annandalei: RGUMF-0074, 15 exs., 55.3-99.0 mm SL, Kameng river, Balukpung, West Kameng District, Arunachal Pradesh (Brahmaputra basin), coll. Karsen Nyori \& Mrinali Choudhuri, 20.viii.2005; RGUMF-0075, 10 exs., 65.0-85.0 mm SL, Panye River, Tamen, Lower Subansiri District, 17.vii.2005. Garra lissorhynchus: MUMF 41634166, 6 exs., 67.1-86.2 mm SL, Iyei River at Noney, Tamenglong district (Brahmaputra basin), coll. K. Nebeshwar, 2.ix.2000. Garra naganensis: MUMF 4156-4159, 4 exs. 92.3-106.9 mm SL, Barak River, Vanchengphai Village, Tamenglong District, Manipur (Brahmaputra basin), coll. K. Nebeshwar, 20.xi.1999; uncatalogued specimen, 2 exs., 77.8-84.4 mm SL, Tuivai River, Churachandpur District, Manipur (Brahmaputra basin), coll. K. Shanta Devi, March 2003. Garra abhoyai: uncatalogued specimen, 6 exs., 45.2-47.0 mm SL, Khujailok stream at Nambol, Bishnupur district, Manipur (Chindwin basin), coll. Vishwanath et al., April 2001; uncatalogued specimen, 6 exs., 49.3-54.9 mm SL, Iril River at Phungthar, Ukhrul district, Manipur (Chindwin basin), coll. I. Linthoi et al., 17.i.2003; uncatalogued specimen, 5 exs., 45.0-53.0 mm SL, Nambul River at Singda, Imphal district, Manipur (Chindwin basin), coll. Joyshree, 3.iii.2004. Garra compressus: MUMF 2316, holotype, 68.1mm SL ; MUMF 2314-2315, paratype, 2exs., 78.6-83.2 mm SL, Wanze stream at Khamson, Ukhrul District, Manipur (Chindwin basin), coll. L. Kosygin, 17.iii.1998. Garra paralissorhynchus: 
Table 2. Comparative morphometric data and meristic count of Garra kalpangi sp. nov. from its nine congeners.

\begin{tabular}{|c|c|c|c|c|c|c|c|c|c|c|}
\hline $\ln \% \mathrm{SL}$ & Gka & Gar & Gma & Gke & Gann & Gna & Gli & Gpa & Gab & Gco \\
\hline Body depth & $18.9-23.8$ & & & & & & & $23.7-26.7$ & $16.2-18.3$ & $16.9-18.2$ \\
\hline Head height & $14.6-16.7$ & & & & $16.4-18.2$ & & & $18.1-21.0$ & & $12.0-12.9$ \\
\hline Head width & $17.3-19.3$ & $19.3-21.2$ & $20.2-22.8$ & $20.0-20.8$ & & & & $20.0-21.3$ & $13.8-15.9$ & \\
\hline Snout length & $12.9-16.4$ & & & & & $11.1-12.6$ & & $10.6-12.5$ & $10.8-11.3$ & $10.3-11.2$ \\
\hline Interorbital space & $8.7-10.1$ & $10.9-13.2$ & $11.1-12.0$ & $12.0-13.1$ & $11.5-11.9$ & & $11.5-12.7$ & & & \\
\hline Dorsal-fin base length & $14.5-16.2$ & & $11.0-13.0$ & & & & $10.5-12.2$ & & $10.6-12.7$ & \\
\hline Dorsal-fin height & $21.9-25.7$ & & & & & & $18.6-19.7$ & $18.6-21.2$ & 17.0-18.8 & \\
\hline Anal-fin base length & $6.7-7.7$ & & & & & & $5.6-6.0$ & & & $7.8-8.2$ \\
\hline Predorsal length & $43.9-50.2$ & & & & & & & $50.2-54.0$ & $51.5-55.1$ & \\
\hline Pre-anus length & $69.5-74.9$ & $62.4-65.6$ & & $62.8-65.0$ & & & & & & $61.3-63.6$ \\
\hline Disc width & $10.3-12.1$ & $14.4-15.4$ & & $14.3-15.4$ & & & $13.4-14.0$ & $12.0-13.0$ & $12.5-13.2$ & \\
\hline Disc length & $8.3-9.9$ & & & $10.7-11.9$ & $6.1-7.1$ & $6.1-7.5$ & $10.0-10.7$ & & & $10.6-11.7$ \\
\hline Callous pad width & $7.3-8.1$ & $9.0-10.1$ & & $8.9-9.6$ & & & $9.5-10.3$ & & & $8.1-8.8$ \\
\hline Callous pad length & $4.8-5.5$ & $6.3-7.7$ & & $6.5-7.4$ & & $2.9-3.8$ & $6.4-7.7$ & & & $7.0-7.8$ \\
\hline \multicolumn{11}{|l|}{ In \% pelvic-anal } \\
\hline Vent-anal distance & $19.9-27.7$ & $32.6-60.0$ & & $50.0-52.9$ & $30.0-33.6$ & $40.6-44.2$ & $37.3-40.2$ & $31.7-35.2$ & $38.2-46.5$ & $48.5-51.5$ \\
\hline \multicolumn{11}{|l|}{ Meristic count } \\
\hline Lateral line scales & $32-33$ & $35-36$ & $34-35$ & $40-42$ & $34-35$ & $36-38$ & $34-35$ & & $34-36$ & 40 \\
\hline Predorsal scales & $10-11$ & & & 13 & & $13-14$ & $14-15$ & & $18-29$ & $13-14$ \\
\hline $\begin{array}{l}\text { Circumpeduncular } \\
\text { scales }\end{array}$ & 16 & & & 12 & & & & & & $12-14$ \\
\hline Dorsal-fin rays & ii-iii, 8 & ii, 7 & ii, 7 & & & & ii, 6 & ii, 6 & ii, 6 & ii,7 \\
\hline Anal-fin rays & ii-iii, 5 & & ii, 4 & & & & ii, 4 & ii, 4 & ii, 4 & \\
\hline Transverse scales & $31 / 2 / 31 / 2$ & & $4 \frac{1}{2} / 4 \frac{1}{2}$ & $4 \frac{1}{2}-5 / 2 \frac{1}{2}$ & & $4 \frac{1}{2} / 4 \frac{1}{2}$ & & & $\begin{array}{l}41 / 2-51 / 2 / \\
41 / 2-51 / 2\end{array}$ & \\
\hline
\end{tabular}

Gka - G. kalpangi sp. nov.; Gar - G. arupi; Gma - G. manipurensis; Gke - G. kempi; Gan - G. annandalei; Gna - G. naganensis; Gli - G. lissorhynchus; Gpa - G. paralissorhynchus; Gab - G. abhoyai; Gco - G. compressus

MUMF 5054, holotype, 65.9mm SL, Khuga River, Churachandpur District, Manipur (Chindwin basin), coll. L. Shanta Devi; Paratype: MUMF 5094, 1 ex., 60.9mm SL, 10.iv.2000; MUMF 5041, 1 ex., 58.0mm SL, 03.v.2000; MUMF 5104-5106, 3 exs., 49.6-59.6 mm SL, 21.viii.2002, same collection data as holotype. -Garra manipurensis: MU/LSD/F-130, holotype, $59.8 \mathrm{~mm}$ SL, Manipur River, Sherou, Manipur (Chindwin basin); MUMF 4160-4162, 3 exs. 41.9-68.3 mm SL, Iyei River, Noney, Tamenglong District (Brahmaputra basin), coll. K. Nebeshwar, 27.xii.2000. Garra kempi: RGUMF-0184, 3 exs., 52.0-56.0 mm SL, Egar stream, Rottung, East Siang District, Arunachal Pradesh (Brahmaputra basin), coll. K. Nebeshwar \& Party, 12. i. 2007; MUMF 4314/2, 2 ex., 64.5-65.0 mm SL, Demwe stream, Tezu, Lohit District, Arunachal Pradesh (Brahmaputra basin), coll. K. Nebeshwar \& Party, 1.i.2007. Garra arupi:
RGUMF-0184, holotype, $60.0 \mathrm{~mm}$ SL; RGUMF-0185, Paratype, 15 exs., 50.0-72.4 mm SL, Deopani River at Roing, Lower Divang Valley, Arunachal Pradesh, coll. K. Nebeshwar \& party, 7-18.ii.2007. Garra litanensis: MUMF-68/1, holotype, 92.5mm SL, Litan stream at Litan, Manipur, coll. W. Vishwanath, 16.iii.1986; MUMF-69/1-5, Paratypes, 5 exs., 69.0-74.0 mm SL, same data as holotype, coll. W. Vishwanath, 12.ii.1988. Garra cf. gotyla: MUMF 4300, 4301/9, 68.8-104.3 mm SL, Tista R., Sikkim (Brahmaputra basin), coll. W. Vishwanath and party, 2-9.ii.2006. Garra sp.: uncatalogued specimens, 2 exs., 81.2-100.3 mm SL, Khasi hills, Meghalaya (Brahmaputra basin), coll. Manichandra, August 2009; uncatalogued specimens, 12 exs., 66.4-122.0 mm SL, Tuirial River, Aizwal, Mizoram (Brahmaputra basin), coll. K. Nebeshwar \& A. Darshan, 24.xi.-1.xii. 2008. 
The taxonomic keys to the sixteen species of Garra distributed in the northeastern states of India

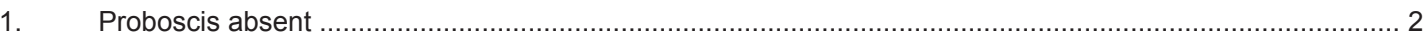

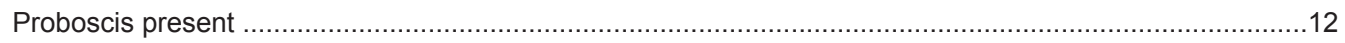

2. Snout tip with a transverse groove or band of tubercles .............................................................. 3

Snout tip smooth, without a transverse groove or band of tubercles ..................................................... 4

3. Lateral line with 35-36 pored scales; No lateral longitudinal band from gill opening to caudal base

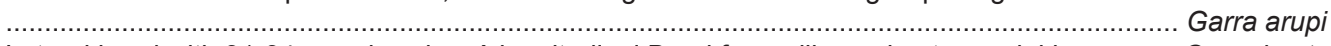
Lateral band with 31-34 pored scales; A longitudinal Band from gill opening to caudal base ........Garra lamta

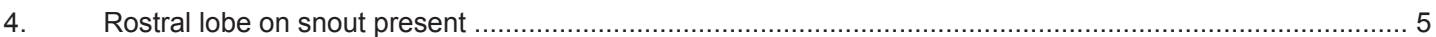

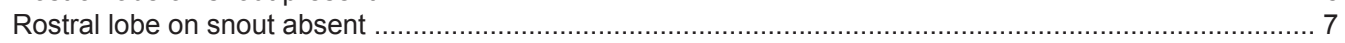

5. W-shaped band on caudal fin absent ................................................................... Garra manipurensis

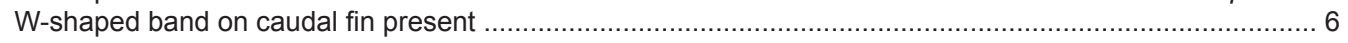

6. Lateral line with 32-33 pored scales; 11-12 predorsal scales ..................................... G. paralissorhynchus Lateral line with 34-35 pored scales; $14-15$ predorsal scales ....................................... Garra lissorhynchus

7. W-shaped band on caudal fin present .......................................................................... Garra abhoyai

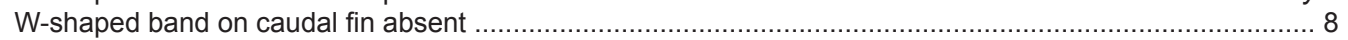

8. Rostral cap groove deep, long, extending to base of rostral barbel ................................. Garra annandalei Rostral cap groove shallow, short, not extending to base of rostral barbel .............................................. 9

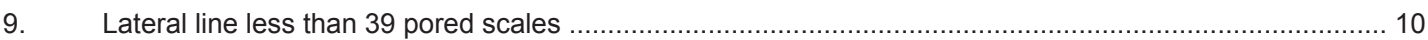

Lateral line more than 39 pored scales ......................................................................................... 11

10. Lateral line with 35 pored scales; Rows of open pores on dorsum of head present ................Garra rupecula Lateral line with 36-38 pored scales; Rows of open pores on dorsum of head absent ........Garra naganensis

11. Black dark spot at upper angle of gill opening and median longitudinal black band on caudal fin present ....... Garra compressus

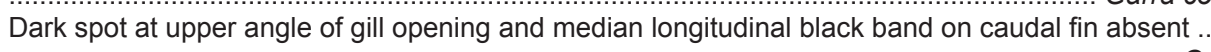

Garra kempi

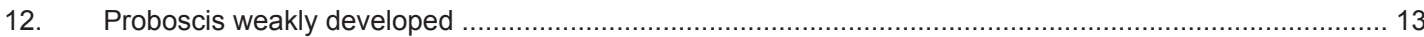

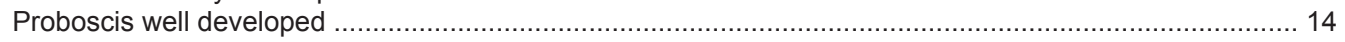

13. Lateral line with 40-41 pored scales; $14-15$ predorsal scales ............................................ Garra elongata Lateral line with 32-33 pored scales; $10-11$ predorsal scales ................................. Garra kalpangi sp. nov.

14. Tubercles of proboscis multicuspid; Proboscis trilobed ....................................................... Garra nasuta Tubercles of Proboscis unicuspid; proboscis uni- or bilobed proboscis ............................................. 15

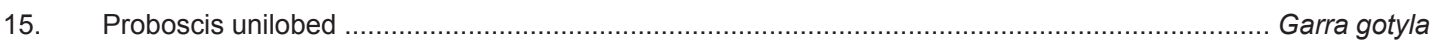

Proboscis bilobed .................................................................................................. Garra litanensis

\section{REFERENCES}

Chen, Z.M., S. Zhao \& J.X. Yang (2009). A new species of the genus Garra from Nujiang River basin, Yunnan, China (Teleostei: Cyprinidae). Zoological Research 30(4): 438-444.

Hora, S.L. (1921). Indian cyprinoid fishes belonging to the genus Garra, with notes on related species from other countries. Records of Indian Museum 22: 633-687.

Kosygin, L. \& W. Vishwanath (1998). A new cyprinid fish Garra compressus from Manipur, India. Journal of Freshwater Biology 10(1-2): 45-48.

Kullander, S.O. \& F. Fang (2004). Seven new species of Garra (Cyprinidae: Cyprininae) from the Rakhine Yoma, southern Myanmar. Ichthyological Exploration of Freshwaters 15(3): 257-278.

Menon, A.G.K. (1964). Monograph of the cyprinid fishes of the genus Garra Hamilton. Memoirs of the Indian Museum 14(4): 173-260.

Nath, P. \& S.C. Dey (2000). Fish and Fisheries of North Eastern India (Arunachal Pradesh). Narendra Publishing House, New Delhi, 217pp.

Nebeshwar, K., W. Vishwanath \& D.N. Das (2009). Garra arupi, a new cyprinid fish species (Pisces: Teleostei) from upper Brahmaputra basin in Arunachal Pradesh, India. Journal of Threatened Taxa 1(4): 197-202.

Vishwanath, W. (1993). On a collection of fishes of the genus Garra Hamilton from Manipur, India, with description of a new species. Journal of Freshwater Biology 5(1): 59-68.

Vishwanath, W. \& L. Kosygin (2000). Garra elongata, a new species of the subfamily Garrinae from Manipur, India (Cyprinidae, Cypriniformes). Journal of the Bombay Natural History Society 97: 408-414.

Vishwanath, W. \& I. Linthoingambi (2008). Redescription of Garra abhoyai Hora (Teleostei: Cyprinidae: Garrinae) with a note on Garra rupecula from Manipur, India. Journal of the Bombay Natural History Society 105(1): 101-104.

Vishwanath, W. \& C. Sarojnalini (1988). A new cyprinid fish, Garra manipurensis, from Manipur, India. Japanese Journal of Ichthyology 35: 124-126.

Vishwanath, W. \& K. Shanta (2005). A new species of the genus Garra Hamilton-Buchanan (Cypriniformes: Cyprinidae) from Manipur, India. Journal of the Bombay Natural History Society 102(1): 86-88.

Zhang, E. (2006). Garra rotundinasus, a new species of cyprinid 
fish (Pisces: Teleostei) from the upper Irrawaddy River basin, China. Raffles Bulletin of Zoology 54(2): 447-453.

Zhang, E. \& Y.Y. Chen (2002). Garra tengchongensis, a new cyprinid species from the upper Irrawaddy River basin in Yunnan, China (Pisces: Teleostei). Raffles Bulletin of Zoology 50(2): 459-464.

Zhang, E., S.P. He \& Y.Y. Chen (2002). Revision of the cyprinid genus Placocheilus Wu, 1977 in China, with description of a new species from Yunnan. Hydrobiologia 487: 207-217.
Author Contribution: The study: DND exploration of fish species in the region. KB collection and habitat description of the fish species from different rivers of Arunachal Pradesh. KN morphometric study and confirmation of the identity of the species. Current paper: DND supervised the work and interpreted the taxonomic information gathered by the fellow researcher. KB collected the specimens, helped in comparative studies of the species and incorporated several revision of the research paper. $\mathrm{KN}$ examined

the specimen and compared with closely related species to establish identity of the new species.

Appendix I . Morphometric characters of G. kalpangi sp. nov.

\begin{tabular}{|c|c|c|c|c|c|c|c|c|c|c|}
\hline \multirow{2}{*}{$\begin{array}{l}\text { Parameters } \\
\text { Standard length }\end{array}$} & \multirow{2}{*}{$\begin{array}{c}\text { Holotype } \\
60.4\end{array}$} & \multicolumn{9}{|c|}{ Paratypes } \\
\hline & & 50.0 & 52.0 & 52.2 & 52.7 & 56.3 & 62.3 & 63.3 & 68.4 & 72.4 \\
\hline \multicolumn{11}{|l|}{ In \% SL } \\
\hline head length & 24.3 & 21.1 & 21.9 & 22.0 & 21.8 & 23.2 & 23.7 & 22.6 & 24.0 & 24.7 \\
\hline head height at nape & 14.8 & 14.6 & 15.7 & 15.3 & 15.6 & 15.7 & 16.6 & 16.6 & 16.6 & 16.7 \\
\hline snout length & 12.0 & 10.3 & 10.2 & 10.2 & 9.1 & 10.5 & 11.4 & 9.2 & 10.2 & 11.6 \\
\hline eye diameter & 5.8 & 5.1 & 6.4 & 6.3 & 5.2 & 5.1 & 5.5 & 5.9 & 5.8 & 6.7 \\
\hline interorbital space & 10.0 & 9.5 & 9.5 & 9.7 & 9.7 & 9.2 & 9.5 & 8.7 & 9.4 & 10.1 \\
\hline body width at anal fin & 10.2 & 8.6 & 10.3 & 10.2 & 10.5 & 10.1 & 9.8 & 9.2 & 10.1 & 10.3 \\
\hline dorsal-fin length & 22.6 & 21.9 & 22.3 & 22.2 & 22.1 & 22.0 & 23.6 & 24.1 & 24.0 & 25.7 \\
\hline dorsal-fin base length & 14.6 & 14.5 & 15.3 & 15.3 & 16.2 & 15.6 & 14.9 & 14.5 & 16.1 & 16.2 \\
\hline pectoral-fin length & 20.7 & 20.4 & 20.8 & 21.8 & 21.1 & 20.5 & 22.0 & 22.0 & 21.5 & 24.5 \\
\hline ventral-fin length & 18.0 & 18.5 & 17.8 & 18.2 & 18.5 & 18.8 & 18.7 & 18.5 & 19.5 & 21.3 \\
\hline anal-fin length & 18.2 & 17.9 & 18.6 & 18.9 & 19.2 & 18.6 & 18.8 & 19.6 & 19.9 & 20.0 \\
\hline anal-fin base length & 6.8 & 6.7 & 7.6 & 7.5 & 7.6 & 7.5 & 7.5 & 7.4 & 7.3 & 7.7 \\
\hline upper caudal-fin lobe length & 26.4 & 26.0 & 26.8 & 26.6 & 26.4 & 27.8 & 29.3 & 28.2 & 29.6 & 30.0 \\
\hline lower caudal-fin lobe length & 27.3 & 26.3 & 27.5 & 28.5 & 28.1 & 28.6 & 28.0 & 29.6 & 30.5 & 31.4 \\
\hline anus-anal distance & 5.6 & 4.5 & 5.0 & 5.3 & 4.4 & 4.8 & 5.5 & 5.8 & 5.9 & 6.2 \\
\hline disc length & 9.2 & 8.3 & 9.4 & 9.9 & 8.6 & 8.8 & 9.1 & 9.4 & 9.7 & 9.9 \\
\hline disc width & 11.8 & 10.5 & 11.1 & 10.6 & 10.8 & 11.0 & 11.3 & 11.6 & 12.0 & 12.1 \\
\hline callous pad length & 5.3 & 4.8 & 4.9 & 5.0 & 5.4 & 4.8 & 5.1 & 4.9 & 4.9 & 5.5 \\
\hline callous pad width & 7.5 & 7.3 & 7.8 & 7.9 & 7.4 & 7.6 & 8.1 & 7.8 & 8.0 & 7.4 \\
\hline \multicolumn{11}{|l|}{ In $\% \mathrm{HL}$} \\
\hline snout length & 44.6 & 41.3 & 42.5 & 42.6 & 42.2 & 44.1 & 46.1 & 46.3 & 47.1 & 49.3 \\
\hline eye diameter & 23.2 & 23.1 & 25.5 & 24.7 & 25.6 & 24.6 & 25.8 & 26.9 & 26.4 & 27.8 \\
\hline interorbital space & 37.3 & 39.6 & 42.7 & 43.4 & 39.4 & 38.7 & 42.0 & 40.8 & 43.4 & 42.4 \\
\hline disc length & 25.2 & 34.6 & 35.4 & 34.6 & 36.3 & 36.5 & 37.8 & 38.1 & 37.2 & 37.9 \\
\hline disc width & 48.1 & 48.7 & 46.0 & 48.7 & 50.3 & 47.5 & 48.7 & 50.6 & 50.8 & 54.4 \\
\hline callous pad length & 19.9 & 19.5 & 21.9 & 21.6 & 22.8 & 22.1 & 22.4 & 22.7 & 23.0 & 24.4 \\
\hline callous pad width & 33.9 & 33.5 & 32.8 & 32.5 & 32.9 & 33.4 & 33.5 & 33.9 & 33.2 & 35.0 \\
\hline
\end{tabular}

